\title{
Obesity, Inflammation, and Insulin Resistance - A Mini-Review
}

\author{
Maximilian Zeyda Thomas M. Stulnig \\ Clinical Division of Endocrinology and Metabolism, Department of Medicine III, Medical University of Vienna, \\ Vienna, Austria
}

\section{Key Words}

Obesity · Adipose tissue - Inflammation • Macrophages • Insulin resistance $\cdot$ Type 2 diabetes mellitus

\begin{abstract}
The association of obesity, insulin resistance, and chronic low-grade inflammation has been evident for several years by now. Since obesity, insulin resistance, and inflammation all are related to aging as well, the mechanisms underlying this association are of critical importance for gerontology. Although several molecular and cellular mechanisms by which inflammatory events decrease the sensitivity to insulin in obese patients have recently been elucidated, the pathogenesis of obesity-induced insulin resistance is still obscure in many aspects. This review aims at giving a general view on the known mechanisms and summarizing the recent progress. Research currently focuses on adipose tissue inflammation as predominantly driven by adipose tissue macrophages, but also related alterations in other organs (liver, muscle, pancreas) have to be considered. Moreover, novel approaches for treatment and prevention of insulin resistance and type 2 diabetes by targeting obesity-induced inflammatory processes are discussed here.
\end{abstract}

Copyright $\odot 2009$ S. Karger AG, Basel
(C) 2009 S. Karger AG, Basel

0304-324X/09/0554-0379\$26.00/0

Fax +4161306 1234

E-Mail karger@karger.ch

www.karger.com
Accessible online at:

www.karger.com/ger

\section{Obesity, Insulin Resistance, and Aging}

The prevalence of obesity leading to decreased life expectancy due to, e.g., type 2 diabetes (T2DM) and cardiovascular disease is dramatically escalating. In the $\mathrm{UK}$, for instance, rates of obese (body mass index $\geq 30 \mathrm{~kg} / \mathrm{m}^{2}$ ) have increased by $30 \%$ in women, $40 \%$ in men, and $50 \%$ in children within the last decade resulting in $23 \%$ of adults being obese in 2007 and a prognosis of 50\% for 2050. The causes underlying the obesity epidemic are still not entirely understood, but its consequences are already apparent, e.g. by the dramatic increase in T2DM nowadays even occurring in children. Obesity, particularly central obesity, is the prominent risk factor for insulin resistance and results in T2DM and other features of the metabolic syndrome such as dyslipidemia and hypertension.

Insulin resistance is determined by impaired sensitivity to insulin of its main target organs, i.e. adipose tissue, liver, and muscle. Insulin regulates glucose uptake and circulating free fatty acid (FFA) concentrations. In adipose tissue, insulin decreases lipolysis thereby reducing FFA efflux from adipocytes; in liver, insulin inhibits gluconeogenesis by reducing key enzyme activities, and in skeletal muscle insulin predominantly induces glucose uptake by stimulating the translocation of the GLUT4 glucose transporter to the plasma membrane. Insulin resistance leads to increased circulating FFA concentrations and ectopic fat accumulation that impede insulinmediated glucose uptake in skeletal muscle and elevated

Thomas M. Stulnig, MD

Department of Medicine III, Clinical Division of Endocrinology and Metabolism Währinger Gürtel 18-20, AT-1090 Vienna (Austria)

Tel. +43140400 4368, Fax +43140400 7790

E-Mail thomas.stulnig@meduniwien.ac.at 
glucose production in liver. Finally, insulin resistance together with abnormalities in insulin secretion leads to T2DM.

The risk for T2DM, in association with the factors of the metabolic syndrome, i.e., abdominal obesity, impaired glucose metabolism, dyslipidemia, and hypertension, increases in aging as recently reviewed in Gerontology [1]. This age-related increase is mainly attributed to an increased prevalence in overweight and obesity in the elderly. Hence, the relationship of obesity, insulin resistance and inflammation as well as putative treatment and prevention strategies as discussed in this review is of particular importance for considerations to reduce morbidity and improve quality of life in an elderly population.

\section{Insulin Resistance on the Signaling Level}

Insulin binding to its receptor induces complex signaling cascades. Very briefly, insulin receptor-mediated tyrosine phosphorylation of insulin receptor substrates (IRS) leads to activation of two major pathways. The phosphatidylinositol 3-kinase $\left(\mathrm{PI}_{3} \mathrm{~K}\right)$-AKT pathway is largely responsible for insulin action on glucose uptake and suppression of gluconeogenesis. The MAPK pathway regulates gene expression and additionally interacts with the $\mathrm{PI}_{3} \mathrm{~K}-\mathrm{AKT}$ pathway to control cell growth and differentiation. Of note, several mediators of insulin-induced signaling independent of IRS and $\mathrm{PI}_{3} \mathrm{~K}$ have been described.

In contrast to activating tyrosine phosphorylation, serine phosphorylation of IRS on critical serine sites blocks insulin signaling. Serine kinases that phosphorylate IRS1 and thus inactivate its activity in insulin signaling are, for instance, I kappa B kinase beta (IKK- $\beta$ ), C-jun $\mathrm{N}$-terminal kinase (JNK)1 and other mitogen-activated protein kinases (MAPK). JNK as well as other IRS serine kinases are activated by insulin, indicating a negative feedback mechanism for the insulin-signaling pathway. Strikingly, the named serine IRS kinases are typical mediators of inflammatory signaling pathways, providing an inhibitory crosstalk between inflammatory and insulin signaling on a molecular level. Other important molecular mediators that link cytokine signaling to inhibition of insulin signaling are suppressor of cytokine signaling (SOCS) 1 and 3 and nitric oxide (NO). SOCS proteins are induced during inflammation, e.g. by interleukin (IL)-6, and induce ubiquitinylation and degradation of IRS proteins. NO is an endogenous signaling molecule that is produced by nitric oxide synthase (iNOS), which is inducible by a variety of inflammatory cytokines. NO has been shown to induce the degradation of IRS1 and iNOS activity results in reduced activity of Akt, the main mediator of IRS signaling.

\section{Inflammatory Mediators in Obesity and Their Effects on Insulin Sensitivity}

In the recent years, more and more evidence has emerged that obesity is associated with inflammation that is causally involved in the development of insulin resistance. In obese patients, a chronic low-grade inflammation occurs as determined by increased plasma levels of C-reactive protein, inflammatory cytokines such as TNF- $\alpha$, IL-6, MCP-1, and IL-8, and the multifunctional proteins leptin [2] and osteopontin [3]. Aging is also well known to be associated with chronic low-grade increases in circulating levels of inflammatory markers. Specifically TNF- $\alpha$ and IL- 6 have been described to be indicators and cause of morbidity and mortality in elderly [4]. Strikingly, inflammation is prominent in particular in diabetic elderly patients [5]. Moreover, systemic inflammation is markedly evident in a number of mouse models of obesity that are widely used for studying its pathogenesis.

Neutralizing TNF- $\alpha$ in rats provided first compelling evidence that inflammatory mediators can cause insulin resistance [6]. Moreover, knockout mice deficient in TNF- $\alpha\left(\operatorname{Tnf}^{-1}\right)$ or the Tnf- $\alpha$ receptor 1 gene (Tnfrl) are protected from insulin resistance induced by both diet and genetic obesity (ob/ob mice) [7]. In vitro experiments with cultured murine adipocytes demonstrated that Tnf$\alpha$ activates several pathways linked to insulin resistance, as detailed above, namely IKK- $\beta$ [8] and SOCS3 [9]. In addition, TNF- $\alpha$ could affect insulin sensitivity by altering the expression of the genes for insulin receptor, IRS1, GLUT4, adiponectin, and PPAR $\gamma$.

Similarly, other inflammatory cytokines interfere with insulin signaling, e.g. IL-1 provokes IRS1 serine phosphorylation by activating ERK [10], and IL- 6 blocks IRS-mediated insulin signaling in liver and muscle via SOCS proteins [11]. Chronically elevated circulating IL-6 levels generated by electro-transfer-mediated overexpression in muscle lead to impaired insulin-stimulated glucose uptake in skeletal muscles [12]. However, IL-6 overexpression also reduces body weight [12], and under certain conditions elevated systemic IL- 6 concentrations even improve insulin sensitivity [13]. Thus the role of IL6 in obesity-mediated insulin resistance remains contro- 
versial. In contrast to inflammatory cytokines, anti-inflammatory mediators such as IL-10 and adiponectin exert insulin-sensitizing effects.

Although a direct effect of for Mcp-1 on insulin resistance has been described, the probable main mechanism how chemokines such as MCP-1 and IL- 8 affect insulin sensitivity is by attracting macrophages particularly into adipose tissue. Once having infiltrated the tissue, macrophages become the major source of inflammatory mediators. Several cytokines that are elevated in obesity, for instance TNF- $\alpha$, potently activate macrophages. Osteopontin induces a variety of cytokines and chemokines in myeloid cells that may lead to further recruitment and activation of macrophages. Furthermore, leptin induces inflammatory mediator production including MCP-1. Since macrophages are not only the major source but also a target of inflammatory mediators, they are supposed to be central players in a vicious circle driving inflammation and insulin resistance. An important role of macrophages in development of systemic insulin resistance was demonstrated by showing that myeloid-selective block of inflammatory NF- $\kappa B$ signaling by deletion of IKK- $\beta$ reduces ageing-, high fat-diet-, and obesity-induced systemic insulin resistance. On the other hand, hepatocytespecific deletion of IKK- $\beta$ affects only the liver but not systemic insulin sensitivity [14]. Importantly, this role is not limited to TNF- $\alpha$, since diminished macrophage-derived TNF- $\alpha$ production alone is not sufficient to improve insulin sensitivity in obese mice [15].

\section{ER Stress as an Origin of Inflammation}

The primary cause for obesity-induced inflammation is not yet fully understood. A potential basis for the initiation of inflammation in obesity is endoplasmic reticulum (ER) stress. Overnutrition and obesity cause ER stress in liver and adipose tissue due to excess lipid accumulation and disturbed energy metabolism [16]. ER stress activates a stress response signaling network termed the unfolded protein response (UPR) that drives protective but also apoptotic and, of note, inflammatory reactions. During ER stress, transmembrane proteins become activated, including the protein kinase/endoribonuclease IRE1, which initiates non-spliceosomal splicing of the mRNA for the transcription factor XBP-1 that controls protective responses to ER stress. IRE1 also induces an inflammatory signaling cascade by activating IKK, the MAPKs p38 and JNK, and finally the major inflammatory transcription factor NF- $\mathrm{kB}$. Consequently, obesity- induced ER stress leads to IRS serine phosphorylation and inhibited insulin signaling. The concept of ER stress is supported by data from heterozygous XBP- $1^{+/-}$mice, in which protective responses to ER stress are partially blunted. These mice are particularly prone to insulin resistance even when on a non-susceptible background [16]. On the contrary, administration of chemical chaperones that reduce ER stress results in restoration of insulin sensitivity in obese mice [17]. Furthermore, ER stress has been shown to downregulate expression of GLUT4 in adipocytes [18]. Altogether, ER stress directly affects insulin signaling in insulin target cells, e.g., by inducing inflammatory signaling and contributes to insulin resistance. Particularly the adipose tissue is subject of current investigations to understand stress-sensing pathways in order to discover potential new therapeutic targets to attenuate obesity-induced metabolic diseases.

\section{Adipose Tissue Macrophages: The Major Source of Obesity-Associated Inflammation}

It has long been known that adipose tissue produces large amounts of inflammatory cytokines and chemokines, collectively called adipokines, such as TNF- $\alpha$, IL$1 \beta$, IL-6, and MCP-1, and that adipose tissue is a main contributor to elevated systemic TNF- $\alpha$ concentrations in obesity [6]. A mouse study shows that also aging is related to a higher inflammatory state of the adipose tissue [19]. Despite relatively low difference in fat mass and body weight between young and old mice compared in this study, IL- 6 and TNF- $\alpha$ production was significantly increased in gonadal adipose tissue, especially in adipocytes, of the older group [19]. Strikingly, obesity-induced chronically inflamed visceral adipose tissue can transfer systemic inflammation and vascular disease even when transplanted to lean mice [20].

Of note, the main source of inflammatory mediators within murine and human adipose tissue are macrophages [21], although also other cell types, including adipocytes, preadipocytes, vascular endothelial cells, T-lymphocytes, and the mesothelium may contribute. A major finding advancing the understanding of obesityinduced inflammation was the discovery that the marked increase of inflammatory adipokine production in obesity is associated with increased numbers of macrophages in adipose tissue (ATMs, adipose tissue macrophages) of obese mice [22]. Clinical studies have confirmed a correlation between BMI and ATM numbers, particularly in the metabolically relevant visceral adipose tissue, in hu- 
mans [23]. Since adipose tissue is a very large organ, above all in obese individuals, ATMs are most probably critical for the systemic manifestations obesity-induced inflammation. According to the fact that omental adipose tissue is particularly prone to inflammatory alterations and its release of inflammatory adipokines to the portal vein, the presence of macrophages in omental adipose tissue contributes to hepatic fibroinflammatory lesions [24]. In addition, adipocyte function is an important factor for systemic insulin sensitivity and thus the local action of ATMs and their cytokines could critically contribute to systemic insulin resistance.

\section{Attraction of Macrophages to Adipose Tissue}

Obesity promotes necrosis-like adipocyte cell death that is probably based on adipocyte hypertrophy. Dead adipocytes are often found surrounded by ATMs in socalled 'crown-like structures' supposed to scavenge cell debris and free lipid droplets [25]. In subcutaneous as well as visceral adipose tissue these crown-like structures can be observed exclusively in obese patients, although at lower frequency compared to rodent models $[23,25]$. The occurrence of adipocyte death and crown-like structures in non-obese hormone-sensitive lipase mutant mice suggests that metabolic alterations probably involving ER stress provoke chemokine production by dying adipocytes [25]. However, this theory needs to be confirmed and the signals and mediators by which adipocyte necrosis leads to increased ATM recruitment need to be investigated.

The expression of several chemotactic proteins such as Mcp-1 (gene: Ccl2), Mcp-2 (Ccl8), and RANTES (Ccl5) as well as of chemokine receptors as Ccr2 and Ccr5 is increased in the adipose tissue of obese mice. Also in human obese subjects, gene expression of CC chemokines Mcp-1, Mcp-2, Mcp-3 (CCL7), RANTES, MIP-1 $\alpha$ (CCL3) and CCL11 is increased in adipose tissue compared with lean controls [26]. Furthermore, gene expression of CC chemokine receptors CCR1, CCR2, CCR3, and CCR5 is elevated in omental and subcutaneous adipose tissue of obese patients. Importantly, expression of CCR2 and CCR5 is higher in omental than in subcutaneous adipose tissue [26]. Studies in Mcp-1 knockout mice and mice overexpressing Mcp-1 support a role of this chemokine in attracting macrophages to adipose tissue and reduced insulin sensitivity in high-fat diet-induced obesity [27], but these data have not been confirmed by others [28]. Mice deficient for the Mcp-1 receptor Ccr2 showed re- duced macrophage content and improved insulin sensitivity after high-fat diet feeding compared to wild-type animals [29]. ATMs that are newly recruited during highfat diet feeding express more Ccr2 compared to resident ATM [30] supporting the concept that Ccr2 ligands such as Mcp-1, $-2,-3$ and -4 contribute to their attraction. Taking human and murine data, Ccr2 and Ccr5 appear to be crucially involved chemokine receptors, but, however, the decisive factor(s) provoking ATM recruitment to adipose tissue and the mode(s) of its/their induction still have to be clarified.

\section{Activation of Adipose Tissue Macrophages: Classical versus Alternative Activation}

Detailed characterization of human ATMs revealed that by expression of surface markers like the mannose receptor, scavenger receptors, and distinct integrins ATMs phenotypically resemble the anti-inflammatory, alternatively activated type of macrophages (also named M2 in contrast to the classical inflammatory M1 type of macrophages [31]). Also in mice, ATMs express M2associated genes such as Ym1, arginase, IL10, and IL1m (the gene for the IL-1 receptor antagonist) [32, 33]. The factors driving alternative macrophage differentiation in adipose tissue are unknown yet. The marked expression of scavenger receptors and the mannose receptor, together with high endocytic activity [23], implicates a role of ATMs in uptake of lipids and lipoproteins, apoptotic cells, hemoglobin, and glycoproteins and supports the idea that obesity-induced recruitment of macrophages into adipose tissue is due to an increased abundance of necrotic-like adipocytes that need to be removed by ATMs [25]. In accordance with their M2 phenotype ATMs produce anti-inflammatory cytokines such as IL10 and the IL-1 receptor antagonist. On the other hand, ATMs are also able to secrete large amounts of proinflammatory cytokines such as TNF- $\alpha$, IL- 6 , and IL- $1 \beta$ supporting a role of ATMs in obesity-induced adipocyte dysfunction and metabolic disorders [23]. Inflammatory cytokine secretion of isolated ATMs occurs without stimulation and can be augmented by addition of TLR ligands and cytokines such as LPS and IFN $\gamma$, respectively [23].

High-fat diet feeding shifts cytokine expression of murine ATMs from M2- to M1-like patterns by decreasing expression of IL10, Ym1, and arginase and increasing TNF- $\alpha$ and Nos2 (iNOS) [33]. On the other hand, weight reduction promotes the occurrence of M2-like macrophages in adipose tissue of obese patients [34]. ATMs may 
be activated by factors secreted by adipocytes. A recent study shows that adipocytes from old mice, at least in vitro, have a higher capacity to stimulate ATM activation via yet unknown factors than young adipocytes, while, interestingly, the aging-induced elevation of inflammatory genes in the AT in vivo was mainly found in adipocytes themselves [19]. However, whether and how age, high-fat diet, and/or weight gain change the M1/M2 phenotype and cytokine expression in ATMs from obese patients is still unclear. Diet-, obesity-, and aging-induced shifts in ATM populations have not yet been discriminated in obese patients and marker molecules established in murine models such as CD11c [33] do not straightforwardly apply to humans [23]. Altogether, determination of the factors that attract macrophages to the adipose tissue and induce their pro- and anti-inflammatory phenotype and activities in obese and lean individuals, respectively, is one of the most intriguing current issues of obesity research.

\section{TLR4 Linking Obesity and Inflammation}

Fatty acids, in particular saturated fatty acids, activate macrophage like-cells via the lipopolysaccharide (LPS) receptor Toll-like recptor (TLR)4. FFA concentrations are elevated in obesity and could directly induce inflammatory responses in macrophages and even adipocytes. FFA activate NF- $\kappa \mathrm{B}$ and cytokine production in adipocytes and macrophages and induction of inflammatory signaling is blunted in the absence of functional TLR4. Moreover, mice lacking functional TLR4 are substantially protected from high fat diet-induced insulin resistance [35]. These studies suggest TLR4 on adipocytes and macrophages to be a sensor of elevated FFA concentrations, which initiates inflammatory and thus insulin-desensitizing processes.

Another possibility by which TLR4 could link obesity to inflammation is the impact of high-fat diet on circulating LPS (endotoxin) concentrations. In conjunction with CD14, LPS is a potent activator of TLR4. LPS is continuously produced by Gram-negative bacteria in the gut and enters the circulation by chylomicrons, a mode of transport that could be enhanced by absorption of high-fat diet. Hence, feeding a high-fat diet significantly increases endotoxemia in mice [36], and similar was found in a clinical study showing that a high-fat meal elicits lowgrade endotoxemia [37]. Strikingly, endotoxemia not only resulted in adipose tissue inflammation and elevated fasting glycemia and insulinemia due to hepatic insulin resistance, but also induced weight gain [36]. These findings suggest that a high-fat diet-induced endotoxemia can trigger an insulin resistance syndrome including obesity and chronic inflammation. This could be especially relevant for elderly people, because aging, at least in mouse models, was shown to increase the inflammatory response to endotoxemia [38].

\section{Inflammatory Processes in Liver, Muscle, and Other Organs Contributing to Obesity-Induced Insulin Resistance and T2DM}

It has long been recognized that inflammatory mediators affect liver function. For instance, TNF- $\alpha$ stimulates hepatic lipogenesis and promotes hyperlipidemia. Hepatic steatosis that is often associated with obesity provokes low-grade inflammation in the liver via NF- $\kappa \mathrm{B}$ activation and inflammatory cytokine production. Consequently, steatohepatitis can occur in obesity due to hepatocyte stress responses and inflammatory activation, probably by fatty acid-mediated activation of TLR4 [35]. Production of IL- 6 blunts insulin signaling in hepatocytes by increased SOCS3 expression as detailed above [39]. On the other hand, mice deficient in TNF- $\alpha$ or osteopontin [15, and F.W. Kiefer, M. Zeyda, T.M. Stulnig, unpubl. data] are protected from high-fat diet-induced hepatic steatosis. These data indicate a vicious circle of aggravating insulin resistance based on hepatic steatosis and inflammation. This model is supported by data showing that not only metabolic but also inflammatory pathways such as TLR4 are tightly linked to the development of hepatic steatosis [40]. In analogy to adipose tissue, macrophage-like cells could initially translate fatty acid-induced TLR4 activation to hepatic inflammation and insulin resistance. Blocking the NF- $\kappa \mathrm{B}$ pathway selectively in hepatocytes is then sufficient to improve insulin sensitivity even under conditions that lead to steatosis and accumulation of macrophages in the liver [41]. However, the role of resident liver macrophages (Kupffer cells) in the pathophysiology of hepatic steatosis and insulin resistance still needs to be elucidated, but a recent publication indicates that the M1/M2 polarization profile of Kupffer cells crucially affects insulin sensitivity [42].

TNF- $\alpha$ reduces insulin sensitivity also in muscle. Obesity-induced inflammatory cytokines disturbing muscle insulin sensitivity such as TNF- $\alpha$, IL- 6 , but also anti-inflammatory mediators such as IL-10 and adiponectin, are supposed to stem from systemic inflammation that mainly originates from adipose tissue [reviewed in 43]. Only 
recently, a high-fat diet-induced accumulation of bone marrow-derived macrophages was discovered in muscle [44]. Increased skeletal muscle TNF- $\alpha$ expression correlating with inhibitory IRS serine phosphorylation was found in obese insulin-resistant women with previous gestational diabetes mellitus, who are at high risk of T2DM [45]. Hence, obesity-induced inflammation occurs also in muscle and drives insulin resistance locally as well as systemically. In addition, vascular endothelial cells express TLR4 and mediates a high-fat diet induced inflammatory response together with diminished insulin sensitivity [46], suggesting that by provoking vascular inflammation and endothelial dysfunction elevated FFA via TLR4 could contribute to both metabolic and cardiovascular risk in obesity.

Intriguingly, also in pancreatic islets of diabetic patients as well as in several animal models of obesity, a marked infiltration of macrophages has been observed [47]. Furthermore, the inflammatory adipokine leptin impairs glucose-stimulated insulin production of human $\beta$ cells through activation of JNK [48]. Moreover, hyperglycemia induces IL-1 $\beta$ production by pancreatic $\beta$ cells, which putatively contributes to glucotoxicity in human pancreatic islets [49]. Therefore, $\beta$-cell function could be hampered by obesity-induced inflammation thereby contributing to the development of overt T2DM.

\section{Approaches to Treat Insulin Resistance by Targeting Inflammatory Pathways}

Based on data discussed above, interfering with the TLR4/IKK/NF- $\kappa \mathrm{B}$ axis could be a promising strategy to prevent onset of insulin resistance in obese patients. Studies with high-dose salicylate, a known inhibitor of IKK, showed that diet- and obesity-induced insulin resistance can be prevented in animals as well as in clinical settings [50]. In addition, salicylate has been shown to block TNF$\alpha$ induced lipolysis in adipocytes from rats [51] and IL$1 \beta$-induced impairment of $\beta$-cell function [52]. Moreover, IKK inhibition by the novel pharmacological inhibitor AS602868 prevents high-glucose-induced liver steatosis and inflammation [53]. Protection from hepatic steatosis could also improve insulin sensitivity in obese patients.

Since JNK is crucially implicated in the onset of insulin resistance and its inhibition improves insulin sensitivity in obese mice without affecting body weight and food uptake [54], JNK inhibitors may be interesting drugs for treatment of obesity-induced insulin resistance. Whether
JNK inhibitors that are currently developed for blocking inflammation and tumor transformation will also be applicable for treatment of obesity-related diseases such as T2DM will have to be evaluated.

The nuclear receptor PPAR $y$ has a long established role in adipogenesis and is the target of the thiazolidinedione class of drugs, which reduce systemic insulin resistance and improve glycemic control in patients with T2DM. PPAR $\gamma$ is also expressed in macrophages where it blunts inflammatory responses and provokes a shift towards the M2 differentiation. Accordingly, a myeloid cell-specific disruption of PPAR $\gamma$ results in a shift of macrophage differentiation towards the inflammatory M1 type, thereby aggravating insulin resistance [55]. Similar results have been shown for PPAR $\delta$-knockouts [42]. Conversely, the anti-inflammatory effect of thiazolidinediones by activation of PPAR $\gamma$ in macrophages may be a crucial component of their insulin-sensitizing effects and agonizing PPAR $\delta$ may promote a M2 polarization of ATMs and Kupffer cells protecting from insulin resistance.

Prevention of diet-induced adipose tissue inflammation and remodeling by supplementation of a high-fat diet with omega-3 (n-3) polyunsaturated fatty acids (PUFA) $[32,56]$ may also involve PPAR $\gamma$. PUFA-mediated PPAR $\gamma$ activation could decrease ATM numbers, promote M2 differentiation of ATMs as well as differentiation of preadipocytes to adipocytes and adiponectin expression in adipocytes [57]. Important for the possible application of these considerations may be the fact that in an animal model, confirmed by human data, aging was shown to cause diminished PPAR $\gamma$ expression in the adipose tissue [58]. However, the anti-inflammatory mechanisms of PUFA action are manifold and involve PPARindependent effects [59]. Finally, also insulin-sensitizing plant-derived drugs such as resveratrol [60] and abscisic acid may improve insulin sensitivity via anti-inflammatory mechanisms [61].

\section{Conclusions/Outlook}

The obesity epidemic will pose enormous medical challenges in the near future. Since significant weight reduction is very hard to achieve in real-life patient care, patients have to be protected from deleterious consequences of obesity namely T2DM and cardiovascular complication that are based on insulin resistance and inflammation. Elucidation of the mechanisms that link obesity with inflammation and insulin resistance will 
not only contribute to the understanding of the pathophysiology of obesity but also open novel strategies for treatment and prevention of obesity- and aging-related metabolic and cardiovascular diseases.

\section{Acknowledgments}

Supported by the Austrian Science Fund Project No. P18776B11, as part of CCHD (W1205-B09; both to T.M.S.) and the European Community's 7th Framework Programme (FP7/20072013) under grant agreement No. 201608.

\section{References}

1 Lechleitner M: Obesity and the metabolic syndrome in the elderly - a mini-review. Gerontology 2008;54:253-259.

-2 Friedman JM, Halaas JL: Leptin and the regulation of body weight in mammals. Nature 1998;395:763-770.

3 Kiefer FW, Zeyda M, Todoric J, Huber J, Geyeregger R, Weichhart T, Aszmann O, Ludvik B, Silberhumer GR, Prager G, Stulnig TM: Osteopontin expression in human and murine obesity: extensive local up-regulation in adipose tissue but minimal systemic alterations. Endocrinology 2008;149:1350-1357.

4 Bruunsgaard H, Pedersen BK: Age-related inflammatory cytokines and disease. Immunol Allergy Clin North Am 2003;23:15 39.

5 Kalofoutis C, Piperi C, Zisaki A, Singh J, Harris F, Phoenix D, Alaveras A, Kalofoutis A: Differences in expression of cardiovascular risk factors among type 2 diabetes mellitus patients of different age. Ann NY Acad Sci 2006;1084:166-177.

6 Hotamisligil GS, Shargill NS, Spiegelman BM: Adipose expression of tumor necrosis factor- $\alpha$ : direct role in obesity-linked insulin resistance. Science 1993;259:87-91.

7 Uysal KT, Wiesbrock SM, Marino MW, Hotamisligil GS: Protection from obesityinduced insulin resistance in mice lacking TNF- $\alpha$ function. Nature 1997;389:610-614.

8 Hotamisligil GS, Peraldi P, Budavari A, Ellis R, White MF, Spiegelman BM: IRS-1-mediated inhibition of insulin receptor tyrosine kinase activity in TNF- $\alpha$ - and obesity-induced insulin resistance. Science 1996;271: 665-668.

-9 Shi H, Tzameli I, Bjorbaek C, Flier JS: Suppressor of cytokine signaling 3 is a physiological regulator of adipocyte insulin signaling. J Biol Chem 2004;279:34733-34740.

-10 Jager J, Gremeaux T, Cormont M, Le Marchand-Brustel Y, Tanti JF: Interleukin-1 $\beta$ induced insulin resistance in adipocytes through down-regulation of insulin receptor substrate-1 expression. Endocrinology 2007; 148:241-251.

- 11 Weigert C, Hennige AM, Lehmann R, Brodbeck K, Baumgartner F, Schauble M, Haring HU, Schleicher ED: Direct cross-talk of interleukin- 6 and insulin signal transduction via insulin receptor substrate-1 in skeletal muscle cells. J Biol Chem 2006;281:70607067.
12 Franckhauser S, Elias I, Rotter Sopasakis V, Ferre T, Nagaev I, Andersson CX, Agudo J, Ruberte J, Bosch F, Smith U: Overexpression of IL-6 leads to hyperinsulinaemia, liver inflammation and reduced body weight in mice. Diabetologia 2008;51:1306-1316.

13 Pedersen BK, Febbraio MA: Point: Interleukin- 6 does have a beneficial role in insulin sensitivity and glucose homeostasis. J Appl Physiol 2007;102:814-816.

14 Arkan MC, Hevener AL, Greten FR, Maeda S, Li ZW, Long JM, Wynshaw-Boris A, Poli G, Olefsky J, Karin M: IKK- $\beta$ links inflammation to obesity-induced insulin resistance. Nat Med 2005;11:191-198.

15 De Taeye BM, Novitskaya T, McGuinness OP, Gleaves L, Medda M, Covington JW, Vaughan DE: Macrophage TNF- $\alpha$ contributes to insulin resistance and hepatic steatosis in diet-induced obesity. Am J Physiol 2007;293:E713-E725.

- 16 Ozcan U, Cao Q, Yilmaz E, Lee AH, Iwakoshi NN, Ozdelen E, Tuncman G, Gorgun C, Glimcher LH, Hotamisligil GS: Endoplasmic reticulum stress links obesity, insulin action, and type 2 diabetes. Science 2004; 306:457-461.

17 Ozcan U, Yilmaz E, Ozcan L, Furuhashi M, Vaillancourt E, Smith RO, Gorgun CZ, Hotamisligil GS: Chemical chaperones reduce ER stress and restore glucose homeostasis in a mouse model of type 2 diabetes. Science 2006;313:1137-1140.

18 Miller RS, Diaczok D, Cooke DW: Repression of GLUT4 expression by the endoplasmic reticulum stress response in 3T3-L1 adipocytes. Biochem Biophys Res Commun 2007;362:188-192.

19 Wu D, Ren Z, Pae M, Guo W, Cui X, Merrill AH, Meydani SN: Aging up-regulates expression of inflammatory mediators in mouse adipose tissue. J Immunol 2007; 179: 4829-4839.

20 Ohman MK, Shen Y, Obimba CI, Wright AP, Warnock M, Lawrence DA, Eitzman DT: Visceral adipose tissue inflammation accelerates atherosclerosis in apolipoprotein Edeficient mice. Circulation 2008;117:798805.

21 Fain JN: Release of interleukins and other inflammatory cytokines by human adipose tissue is enhanced in obesity and primarily due to the nonfat cells. Vitam Horm 2006;74: 443-477.
22 Weisberg SP, McCann D, Desai M, Rosenbaum M, Leibel RL, Ferrante AW Jr: Obesity is associated with macrophage accumulation in adipose tissue. J Clin Invest 2003;112: 1796-1808.

23 Zeyda M, Farmer D, Todoric J, Aszmann O, Speiser M, Gyori G, Zlabinger GJ, Stulnig TM: Human adipose tissue macrophages are of an anti-inflammatory phenotype but capable of excessive pro-inflammatory mediator production. Int J Obes (Lond) 2007;31: 1420-1428.

24 Cancello R, Tordjman J, Poitou C, Guilhem G, Bouillot JL, Hugol D, Coussieu C, Basdevant A, Hen AB, Bedossa P, Guerre-Millo $\mathrm{M}$, Clement $\mathrm{K}$ : Increased infiltration of macrophages in omental adipose tissue is associated with marked hepatic lesions in morbid human obesity. Diabetes 2006;55:15541561.

25 Cinti S, Mitchell G, Barbatelli G, Murano I, Ceresi E, Faloia E, Wang S, Fortier M, Greenberg AS, Obin MS: Adipocyte death defines macrophage localization and function in adipose tissue of obese mice and humans. J Lipid Res 2005;46:2347-2355.

26 Huber J, Kiefer FW, Zeyda M, Ludvik B, Silberhumer GR, Prager G, Zlabinger GJ, Stulnig TM: CC chemokine and CC chemokine receptor profiles in visceral and subcutaneous adipose tissue are altered in human obesity. J Clin Endocrinol Metab 2008;93:32153221.

27 Kanda H, Tateya S, Tamori Y, Kotani K, Hiasa KI, Kitazawa R, Kitazawa S, Miyachi H, Maeda S, Egashira K, Kasuga M: MCP-1 contributes to macrophage infiltration into adipose tissue, insulin resistance, and hepatic steatosis in obesity. J Clin Invest 2006;116: 1494-1505.

28 Inouye KE, Shi H, Howard JK, Daly CH, Lord GM, Rollins BJ, Flier JS: Absence of CC chemokine ligand 2 does not limit obesityassociated infiltration of macrophages into adipose tissue. Diabetes 2007;56:22422250.

29 Weisberg SP, Hunter D, Huber R, Lemieux J, Slaymaker S, Vaddi K, Charo I, Leibel RL, Ferrante AW: CCR2 modulates inflammatory and metabolic effects of high-fat feeding. J Clin Invest 2006;116:115-124.

30 Lumeng CN, Deyoung SM, Bodzin JL, Saltiel AR: Increased inflammatory properties of adipose tissue macrophages recruited during diet-induced obesity. Diabetes 2007;56: $16-23$. 
-31 Zeyda M, Stulnig TM: Adipose tissue macrophages. Immunol Lett 2007;112:61-67.

- 32 Todoric J, Loffler M, Huber J, Bilban M, Reimers M, Kadl A, Zeyda M, Waldhausl W, Stulnig TM: Adipose tissue inflammation induced by high-fat diet in obese diabetic mice is prevented by $n-3$ polyunsaturated fatty acids. Diabetologia 2006;49:21092119.

-33 Lumeng CN, Bodzin JL, Saltiel AR: Obesity induces a phenotypic switch in adipose tissue macrophage polarization. J Clin Invest 2007;117:175-184.

- 34 Clement K, Viguerie N, Poitou C, Carette C, Pelloux V, Curat CA, Sicard A, Rome S, Benis A, Zucker JD, Vidal H, Laville M, Barsh GS, Basdevant A, Stich V, Cancello R, Langin D: Weight loss regulates inflammation-related genes in white adipose tissue of obese subjects. FASEB J 2004;18:1657-1669.

- 35 Shi H, Kokoeva MV, Inouye K, Tzameli I, Yin $\mathrm{H}$, Flier JS: TLR4 links innate immunity and fatty acid-induced insulin resistance. J Clin Invest 2006;116:3015-3025.

- 36 Cani PD, Amar J, Iglesias MA, Poggi M, Knauf C, Bastelica D, Neyrinck AM, Fava F, Tuohy KM, Chabo C, Waget A, Delmee E, Cousin B, Sulpice T, Chamontin B, Ferrieres J, Tanti JF, Gibson GR, Casteilla L, Delzenne NM, Alessi MC, Burcelin R: Metabolic endotoxemia initiates obesity and insulin resistance. Diabetes 2007;56:1761-1772.

- 37 Erridge C, Attina T, Spickett CM, Webb DJ: A high-fat meal induces low-grade endotoxemia: evidence of a novel mechanism of postprandial inflammation. Am J Clin Nutr 2007;86:1286-1292.

- 38 Saito H, Sherwood ER, Varma TK, Evers BM: Effects of aging on mortality, hypothermia, and cytokine induction in mice with endotoxemia or sepsis. Mech Ageing Dev 2003; 124:1047-1058.

39 Kim JH, Kim JE, Liu HY, Cao W, Chen J: Regulation of interleukin-6-induced hepatic insulin resistance by mammalian target of rapamycin through the STAT3-SOCS3 pathway. J Biol Chem 2008;283:708-715.

-40 Poggi M, Bastelica D, Gual P, Iglesias MA, Gremeaux T, Knauf C, Peiretti F, Verdier M, Juhan-Vague I, Tanti JF, Burcelin R, Alessi MC: $\mathrm{C} 3 \mathrm{H} / \mathrm{HeJ}$ mice carrying a toll-like receptor-4 mutation are protected against the development of insulin resistance in white adipose tissue in response to a high-fat diet. Diabetologia 2007;50:1267-1276.

-41 Wunderlich FT, Luedde T, Singer S, SchmidtSupprian M, Baumgartl J, Schirmacher P, Pasparakis M, Bruning JC: Hepatic NF- $\kappa$ B essential modulator deficiency prevents obesity-induced insulin resistance but synergizes with high-fat feeding in tumorigenesis. Proc Natl Acad Sci USA 2008; 105:12971302.
42 Odegaard JI, Ricardo-Gonzalez RR, Red Eagle A, Vats D, Morel CR, Goforth MH, Subramanian V, Mukundan L, Ferrante AW, Chawla A: Alternative M2 activation of Kupffer cells by PPAR $\delta$ ameliorates obesityinduced insulin resistance. Cell Metab 2008; 7:496-507.

43 Sell H, Eckel J, Dietze-Schroeder D: Pathways leading to muscle insulin resistance the muscle-fat connection. Arch Physiol Biochem 2006;112:105-113.

44 Hevener AL, Olefsky JM, Reichart D, Nguyen MT, Bandyopadyhay G, Leung HY, Watt MJ, Benner C, Febbraio MA, Nguyen AK, Folian B, Subramaniam S, Gonzalez FJ, Glass CK, Ricote M: Macrophage PPAR $\gamma$ is required for normal skeletal muscle and hepatic insulin sensitivity and full antidiabetic effects of thiazolidinediones. J Clin Invest 2007;117:1658-1669.

45 Friedman JE, Kirwan JP, Jing M, Presley L, Catalano PM: Increased skeletal muscle tumor necrosis factor- $\alpha$ and impaired insulin signaling persist in obese women with gestational diabetes mellitus 1 year postpartum. Diabetes 2008;57:606-613.

46 Kim F, Pham M, Luttrell I, Bannerman DD, Tupper J, Thaler J, Hawn TR, Raines EW, Schwartz MW: Toll Like receptor-4 mediates vascular inflammation and insulin resistance in diet-induced obesity. Circ Res 2007; 100:1589-1596

47 Ehses JA, Perren A, Eppler E, Ribaux P, Pospisilik JA, Maor-Cahn R, Gueripel X, Ellingsgaard H, Schneider MK, Biollaz G, Fontana A, Reinecke M, Homo-Delarche F, Donath MY: Increased number of islet-associated macrophages in type 2 diabetes. Diabetes 2007;56:2356-2370.

48 Maedler K, Schulthess FT, Bielman C, Berney T, Bonny C, Prentki M, Donath MY, Roduit R: Glucose and leptin induce apoptosis in human $\beta$-cells and impair glucosestimulated insulin secretion through activation of c-Jun N-terminal kinases. FASEB J 2008;22:1905-1913.

49 Maedler K, Sergeev P, Ris F, Oberholzer J, Joller-Jemelka HI, Spinas GA, Kaiser N, Halban PA, Donath MY: Glucose-induced $\beta$-cell production of IL- $1 \beta$ contributes to glucotoxicity in human pancreatic islets. J Clin Invest 2002; 110:851-860.

-50 Fleischman A, Shoelson SE, Bernier R, Goldfine $A B$ : Salsalate improves glycemia and inflammatory parameters in obese young adults. Diabetes Care 2008;31:289-294.

51 Zu L, Jiang H, He J, Xu C, Pu S, Liu M, Xu G: Salicylate blocks lipolytic actions of tumor necrosis factor- $\alpha$ in primary rat adipocytes. Mol Pharmacol 2008;73:215-223.

52 Zeender E, Maedler K, Bosco D, Berney T, Donath MY, Halban PA: Pioglitazone and sodium salicylate protect human $\beta$-cells against apoptosis and impaired function induced by glucose and interleukin-1 $\beta$. J Clin Endocrinol Metab 2004;89:5059-5066.
53 Beraza N, Malato Y, Vander Borght S, Liedtke C, Wasmuth HE, Dreano M, de Vos R, Roskams T, Trautwein C: Pharmacological IKK2 inhibition blocks liver steatosis and initiation of non-alcoholic steatohepatitis. Gut 2008;57:655-663.

54 Solinas G, Naugler W, Galimi F, Lee MS, Karin M: Saturated fatty acids inhibit induction of insulin gene transcription by JNKmediated phosphorylation of insulin-receptor substrates. Proc Natl Acad Sci USA 2006; 103:16454-16459.

55 Odegaard JI, Ricardo-Gonzalez RR, Goforth MH, Morel CR, Subramanian V, Mukundan L, Eagle AR, Vats D, Brombacher F, Ferrante AW, Chawla A: Macrophage-specific PPARy controls alternative activation and improves insulin resistance. Nature 2007;447:11161120.

56 Huber J, Loffler M, Bilban M, Reimers M, Kadl A, Todoric J, Zeyda M, Geyeregger R, Schreiner M, Weichhart T, Leitinger N, Waldhausl W, Stulnig TM: Prevention of high-fat diet-induced adipose tissue remodeling in obese diabetic mice by $\mathrm{n}-3$ polyunsaturated fatty acids. Int J Obes (Lond) 2007; 31:1004-1013.

57 Neschen S, Morino K, Rossbacher JC, Pongratz RL, Cline GW, Sono S, Gillum M, Shulman GI: Fish oil regulates adiponectin secretion by a peroxisome proliferator-activated receptor- $\gamma$-dependent mechanism in mice. Diabetes 2006;55:924-928.

58 Ye P, Zhang XJ, Wang ZJ, Zhang C: Effect of aging on the expression of peroxisome proliferator-activated receptor- $\gamma$ and the possible relation to insulin resistance. Gerontology 2006;52:69-75.

59 Stulnig TM: Immunomodulation by polyunsaturated fatty acids: mechanisms and effects. Int Arch Allergy Immunol 2003;132: 310-321.

60 Baur JA, Pearson KJ, Price NL, Jamieson HA, Lerin C, Kalra A, Prabhu VV, Allard JS, Lopez-Lluch G, Lewis K, Pistell PJ, Poosala S, Becker KG, Boss O, Gwinn D, Wang M, Ramaswamy S, Fishbein KW, Spencer RG, Lakatta EG, Le Couteur D, Shaw RJ, Navas P, Puigserver P, Ingram DK, de Cabo R, Sinclair DA: Resveratrol improves health and survival of mice on a high-calorie diet. $\mathrm{Na}$ ture 2006;444:337-342.

61 Guri AJ, Hontecillas R, Ferrer G, Casagran O, Wankhade U, Noble AM, Eizirik DL, Ortis F, Cnop M, Liu D, Si H, Bassaganya-Riera $\mathrm{J}$ : Loss of PPAR $y$ in immune cells impairs the ability of abscisic acid to improve insulin sensitivity by suppressing monocyte chemoattractant protein-1 expression and macrophage infiltration into white adipose tissue. J Nutr Biochem 2008;19:216-228. 